\title{
ANALYSIS AND MODELING OF INDUSTRIAL COMPANIES CASH FLOWS UNDER CRISIS CONDITIONS
}

\author{
S. Konstantinova* \\ Faculty of Economics, University of Food Technologies - Plovdiv, Bulgaria
}

\begin{abstract}
For the purpose of an analysis and modeling of cash flows under uncertainty conditions was formed a sample of 16 public industrial companies that are representatives of three groups: group I - companies from SOFIX - main index of Bulgarian Stock Exchange - Sofia AD; group II - companies from BGBX 40; group III - companies that do not participate in the calculation of either of the two indices, but that accumulated considerable investor interest. The study addresses three main types of cash flows: cash flows of business operations; investment operations, and financial operations. Based on the analysis were established levels and trends were revealed. This provides opportunity to draw models and make suggestions to improve the cash flows management.
\end{abstract}

Key words: cash flows, industry, crisis, analysis, model

\section{INTRODUCTION}

A sample of 16 industrial companies (1) has been formed for analysis and modeling of cash flows before and after the global financial and economic crisis (2007-2008). They are representatives of the following groups:

First group: companies whose shares participate in the calculation of the main index SOFIX of Bulgarian Stock Exchange - Sofia AD: Sopharma AD, Neochim AD, Monbat $\mathrm{AD}, \mathrm{M}+\mathrm{S}$ Hydraulic $\mathrm{AD}$ and Albena AD.

Second group: companies that participate in the broad index BGBX 40: Fazerles AD, Yuri Gagarin AD, Biovet AD, Trace Group Hold $\mathrm{AD}$ and Sparky Eltos AD.

Third group - companies that do not participate in the calculation of either of the two indices, but that accumulated considerable investor interest: Alkomet AD, Asenova Krepost AD, Elhim Iskra AD, Zaharni Zavodi $\mathrm{AD}$ and Svilosa AD.

For the exploration of the investment activity was used information from the third major document contained in the annual financial statements of the companies called Statement of cash flows under the direct method $(2,3,4)$, for the relatively lengthy period 2007-2013.

\footnotetext{
*Correspondence to: Assoc. Prof. Snezhinka Konstantinova Stoyanova, PhD, Faculty of Economics, University of Food Technologies Plovdiv, Bulgaria, 4002 Plovdiv, P.B. 27, Bulgaria, Cell Phone: $\quad+359878384372, \quad$ E-mail: sks_ko@abv.bg
}

The information about the cash flows of an enterprise is useful in that it provides a basis for assessment of the ability of the enterprise to generate cash and cash equivalents and the needs of the enterprise to utilize those cash flows. The economic decisions that are made by users require an evaluation of the ability of the enterprise to generate cash and cash equivalents, their timing and the security of their generation. The purpose of the standards is to require the provision of information about the historical changes in cash and cash equivalents of an enterprise by means of a cash flow statement, in which they are categorized in the reporting period from operating, investment and financial activities. The users of financial statements of the enterprise are interested in how the enterprise generates and uses cash and cash equivalents, regardless of the nature of the activity of the enterprise and irrespective of whether cash can be viewed as the product of the enterprise, as may be the case in the financial institutions. The enterprises need cash for reasons that are essentially the same, however different their principal activities that generate revenue. They need cash to conduct their operations, to pay their liabilities and to provide returns to their investors.

\section{METHODS AND TERMS}

The cash flow statement presents cash flows during the reporting period classified by operating, investment and financial activities, 
through direct or indirect method, whereby cash flows of different types of transactions carried out by the enterprise are recognized in various activities on major classes of gross cash receipts and gross payments for the reporting period. In the direct method, information about major classes of gross cash receipts and payments can be obtained from:

a) the accounting records of the enterprise for the movement of its finances;

b) the amount of articles in the statement of income and expenditure, adjusted by the changes in the reporting period in the amount of the articles in the accounting balance sheet, taking into account any changes in these articles that have occurred as a result of transactions carried out without the use of cash.

In accordance with the standards in this work were used the following terms:

1. Cash - short-term financial assets in the form of cash and/or cash equivalents;

2. Cash balances - money available in cash and demand deposits;

3. Cash equivalents - short-term, highly liquid investments that are readily convertible into corresponding sums and that contain an insignificant risk of changes in their value;
4. Cash flows - inflows (revenues) and outflows (payments) of cash and cash equivalents;

5. Operational activities - the principal business activity of the enterprise that generates revenue and other activities that are not investment or financial;

6. Investment activity - acquisition and sale of fixed assets and other investments that are not included in cash equivalents;

7. Financial activity - activity that result in changes in the size and the composition of the contributed equity and the borrowings of the enterprise (5).

\section{RESULTS, MODELS AND DISCUSSION}

The cash flows from operating activities are primarily derived from the principal revenueproducing activity of the enterprise. Therefore, they generally result from the transactions and other events that enter into the determination of profit or loss. The separate disclosure of cash flows generated from financial activities is important, because it helps in predicting the sums from future cash flows that represent receivables of the institutions, which have provided capital of the enterprise (6).

After an analysis and processing of large amounts of information Table 1 was compiled:

Table 1. Net cash flows from the operating activities of industrial companies, (thousand BGN)

\begin{tabular}{|c|c|c|c|c|}
\hline Companies & 2007 & 2009 & 2011 & 2013 \\
\hline 1. Albena AD & 41995 & 27170 & 29118 & 34767 \\
\hline 2. Alkomet AD & 3665 & 10791 & 12812 & -4151 \\
\hline 3. Asenova Krepost AD & -3086 & -529 & 688 & 891 \\
\hline 4. Biovet AD & 14575 & 12638 & 10991 & 24791 \\
\hline 5. Elhim Iskra AD & 327 & 5458 & 562 & 4355 \\
\hline 6. Zaharni Zavodi AD & -3720 & 8444 & -176 & 3891 \\
\hline 7. Zarneni Hrani Bulgaria AD & -7919 & 20031 & 4388 & -2301 \\
\hline 8. M+S Hydraulic AD & 10069 & 11662 & 17693 & 13802 \\
\hline 9. Monbat AD & -350 & 13679 & 29621 & 25346 \\
\hline 10. Neochim AD & 12782 & -22915 & 4879 & 7682 \\
\hline 11. Sopharma AD & 34004 & 37703 & 24051 & 91443 \\
\hline 12. Sparky Eltos AD & -13251 & -7630 & 7710 & 2658 \\
\hline 13. Svilosa AD & -3172 & 1061 & 3690 & 38 \\
\hline 14. Trace Group Hold AD & 4015 & 9908 & 7066 & 25278 \\
\hline 15. Fazerles AD & 5784 & 4627 & 619 & 68 \\
\hline 16. Yuri Gagarin AD & 10493 & 6246 & 7897 & 1924 \\
\hline Total & 106211 & 138344 & 160921 & 233481 \\
\hline
\end{tabular}

\section{- Linear model}

- Second degree polynomial

$$
\begin{gathered}
y=20219 x-4 E+07 \\
R^{2}=0,9331
\end{gathered}
$$

$$
\begin{gathered}
y=2526,7 x^{2}-1 E+07 x+1 E+10 \\
R^{2}=0,9798
\end{gathered}
$$

The author obtained quite unexpected results. It is normal to expect that the crisis will sharply shrink the cash flows from operating activities, particularly for the period 2007- 
2011. During the same period the revenue of companies decreased. But the facts show that the cash flows from operating activities for the research period have increased with almost 220\%! The analysis shows that while in 2007 six companies generated negative cash flow from operating activities; in 2009 their number reduced to three companies, in 2011 - one company, 2013 - two companies. The specific analysis shows that this effect is mainly due to the conservative policy of managers regarding the payments for operating activities. In 2009, payments to suppliers decreased by BGN 37 million compared to those made in 2007, while proceeds from customers increased by BGN 11 million. In 2011 there is a significant increase in the basic cash flows for operating activities:

- Proceeds from customers - increase by BGN 512 million;

- Payments to suppliers - increase by BGN 411 million.

In 2013, the increase is even greater:

- Proceeds from customers - growth of BGN 617 million;

- Payments to suppliers - growth of BGN 508 million.

Regardless of the parallel increases of both basic operational flows, the difference between them for both periods is BGN 100 million in favor of the cash inflows.

The highly restrictive policy regarding the cash outflows also occurs in payments, related to remunerations. Thus, for the period 2007-2009 these payments for the entire group of companies increased by only BGN 3 million. For the next control years, the growth is more significant: 2011 - BGN 23 million; 2013 BGN 27 million.

The analysis of the cash flows from investment activities enabled the drawing of Table 2:

Table 2. Net cash flows from investment activities of industrial companies, (thousand BGN)

\begin{tabular}{|c|c|c|c|c|}
\hline Companies & 2007 & 2009 & 2011 & 2013 \\
\hline 1. Albena AD & -55372 & -7715 & 13103 & -18951 \\
\hline 2. Alkomet AD & -9268 & -4953 & 7394 & -6979 \\
\hline 3. Asenova Krepost AD & -118 & -1647 & -336 & -1645 \\
\hline 4. Biovet AD & -15362 & -5941 & -37308 & -11978 \\
\hline 5. Elhim Iskra AD & -811 & -984 & -1878 & -2814 \\
\hline 6. Zaharni Zavodi AD & -618 & -4594 & -71 & -2756 \\
\hline 7. Zarneni Hrani Bulgaria AD & 15081 & 5833 & 10671 & 19535 \\
\hline 8. M+S Hydraulic AD & -5848 & -4814 & -4185 & -6684 \\
\hline 9. Monbat AD & -25870 & -16796 & -20712 & -28001 \\
\hline 10. Neochim AD & -19414 & -4322 & -8239 & -13169 \\
\hline 11. Sopharma AD & -43159 & -25101 & -43286 & -13890 \\
\hline 12. Sparky Eltos AD & 0 & -2093 & -6119 & -3482 \\
\hline 13. Svilosa AD & 1113 & -385 & -34 & 178 \\
\hline 14. Trace Group Hold AD & -1523 & -4690 & 3601 & -3414 \\
\hline 15. Fazerles AD & -2920 & -4174 & -1839 & -981 \\
\hline 16. Yuri Gagarin AD & -9225 & -1372 & -5885 & -7590 \\
\hline Total & -173314 & -83748 & -95123 & -102621 \\
\hline
\end{tabular}

The data in Table 2 show that in the first years of the researched period the managers sharply reduced the overall risk of the execution of investments. So, in 2009 the net cash flow decreased by nearly BGN 90 million (more than twice), in 2011 the results slightly improved, but the data for 2013 show that Bulgarian industrial companies still cannot get out of the investment shock, caused by the crisis. In other authors' studies (6) the factors forming the investment activity of industrial companies are analyzed and modeled in detail.

\section{- Linear model}

$$
\begin{gathered}
y=10035 x-2 E+07 \\
R^{2}=0,4095
\end{gathered}
$$

- Second degree polynomial

$$
\begin{gathered}
y=-6066,5 x^{2}+2 E+07 x-2 E+10 \\
R^{2}=0,8883
\end{gathered}
$$


For the measurement of security in the investment activity of industrial companies the following models have been compiled (6):
1. Model of the instability of the investment activity of the industrial company, characterized by a certain indicator of this activity:

$$
V o_{i j}=\frac{\sum_{t=1}^{l}\left|Y_{i j t}-Y_{i j t+1}\right|}{t-1},
$$

where $V o_{i j}$ - is a measure of the instability (volatility) of the investment activity of the i-th industrial company, as measured by the $\mathrm{j}$-th indicator of this activity; $Y_{i j t}$ - investment activity of the i-th industrial company, characterized by the $\mathrm{j}$-th indicator in the t-th year of the analyzed period;

$Y_{i j t+1}$ - investment activity of the same company during the next analyzed year; $l$ - number of the analyzed years from the period (in this case $l=4$ );

$m$ - number of explored industrial companies (In this case $m=9$ );

$n$ - number of indicators of investment activity (in this case $n=3$ ).

2. Model of fragmented volatility in the investment activity of the industrial company, characterized by an indicator of this activity:

$$
R u_{i j}=\frac{V o_{i j}}{\bar{Y}_{i j}},
$$

where $R u_{i j}-$ is a coefficient (ratio) of volatility (uncertainty) of the investment activity of the i-th industrial company, characterized by the $\mathrm{j}$-th indicator; $V o_{i j}$ - level of the indicator of instability of the investment activity of the same company; $\bar{Y}_{i j}$ - the arithmetic average of the j-th indicator of the investment activity of the i-th industrial company for the whole analyzed period.

For a better representativeness and comparability of the results this indicator can be presented in percentages.

3. Model of the complex volatility in the investment activity of individual industrial company:

$$
R u_{i}=\frac{\sum_{j=1}^{n} K_{i j} \cdot R u_{i j}}{\sum_{j=1}^{n} K_{i j}} \cdot[100],
$$

where $R u_{i}$ - is a coefficient of the complex volatility of the investment activity of the i-th industrial company;

$K_{i j}$ - relative weight (importance) of the $\mathrm{j}$-th indicator of the investment activity of the i-th industrial company;
$R u_{i j}$ - coefficient of the fragmented volatility of the investment activity of the same company, characterized by the $\mathrm{j}$-th indicator.

In this study the coefficients of significance were determined by the method of the expert assessments, as follows:

- For the indicator Net cash flow from investment activities: $K_{1}=1,00$;

- For the indicator Cash for purchase of fixed assets: $K_{2}=1,26$;

- For the indicator Cash for purchase of investments: $K_{3}=0,74$.

Regardless of the different sectoral affiliation of the studied companies, which created differences in the expert opinions, these coefficients were used for all companies.
4. Model of general volatility in the investment activities of the entire group studied companies:

$$
R u=\frac{\sum_{i=1}^{m} \cdot \sum_{j=1}^{n} K_{i j} \cdot R_{i j}}{\sum_{i=1}^{m} \cdot \sum_{j=1}^{n} K_{i j}} \cdot[100],
$$


where $R u-$ coefficient of the general volatility in the investment activities of the entire group studied companies for the whole analyzed period;

$K_{i j}$ - coefficients of importance of the various indicators of the investment activity (in this particular study $-K_{i j}=K_{j}$ );
$R u_{i j}$ - coefficients of the fragmented volatility of individual companies of the various indicators of the investment activity.

The analysis of the third main group cash flows enabled the drawing of Table 3 :

Table 3. Net cash flows from financing activities of industrial companies, (thousand BGN)

\begin{tabular}{|c|c|c|c|c|}
\hline Companies & 2007 & 2009 & 2011 & 2013 \\
\hline 1. Albena AD & 14263 & -17129 & -21279 & -17082 \\
\hline 2. Alkomet AD & 6277 & -3889 & -6951 & 11709 \\
\hline 3. Asenova Krepost AD & 3651 & 2193 & -403 & 644 \\
\hline 4. Biovet $\mathrm{AD}$ & 756 & -6637 & 25545 & -11312 \\
\hline 5. Elhim Iskra AD & 771 & -697 & -2805 & 145 \\
\hline 6. Zaharni Zavodi AD & 2730 & -3333 & 411 & -1109 \\
\hline 7. Zarneni Hrani Bulgaria AD & -1549 & -28316 & -3636 & -17271 \\
\hline 8. M+S Hydraulic AD & -2481 & -3742 & -4639 & -8511 \\
\hline 9. Monbat AD & 25138 & 4761 & -6962 & 7043 \\
\hline 10. Neochim AD & 990 & 20601 & 4051 & 124 \\
\hline 11. Sopharma AD & 31210 & -9412 & 6291 & -72477 \\
\hline 12. Sparky Eltos AD & 23163 & 10256 & -1655 & 558 \\
\hline 13. Svilosa AD & 2704 & -42 & -3113 & -51 \\
\hline 14. Trace Group Hold AD & 16052 & -5784 & -2048 & -9290 \\
\hline 15. Fazerles AD & -339 & 799 & -1227 & -509 \\
\hline 16. Yuri Gagarin AD & -2656 & -3528 & -371 & -8336 \\
\hline Total & 120680 & -43899 & -18791 & -125725 \\
\hline
\end{tabular}

- Linear model

$$
\begin{gathered}
y=-35705 x+7 E+07 \\
R^{2}=0,8093 \\
-\quad \text { Second degree polynomial } \begin{array}{c}
y=3602,8 x^{2}-1 E+07 x+1 E+10 \\
R^{2}=0,8357
\end{array}
\end{gathered}
$$

The data in Table 3 shows conclusively that before the crisis the industrial companies easily and powerfully financed their operations mainly with foreign capital. For 2007 alone the net cash flow was over BGN 120 million. This cash flow was generated exclusively by foreign capital (receipts of loans), because during that year none of the researched companies issued securities, and therefore there were no revenues from equity. In subsequent years, the picture changed dramatically: in this group the cash flows began to dominate over payments. Thus, for 2009 a negative net cash flow of nearly BGN 44 million was formed. In 2011, the fear of foreign capital seemed to be considerably reduced: minus BGN 19 million, but in 2013 a huge negative cash flow of nearly BGN 126 million was formed. But this specific analysis shows that for 2013 it was formed mainly by Sopharma AD (BGN 63 million - paid loans; BGN 6 million repurchase of securities; BGN 9 million - paid dividends, etc.).
The other two companies that contribute to the large negative balance of this group of cash flows are Albena $\mathrm{AD}$ and Zarneni Hrani Bulgaria AD.

Generally, the analysis of net cash flows from financing activities shows that in the years after the crisis the industrial companies cannot benefit from the favorable leverage and the benefits of the leverage effect of foreign capital on the effectiveness of equity. The cash flows are not poured into, but vice versa, they leave the companies for service of old capital liabilities. One of the main reasons for this is the restrictive policy of banks towards the industrial companies, particularly in terms of the investment credits. The banks in Bulgaria, most of which are subsidiaries of foreign banks, prefer to give consumer and mortgage loans to the population, instead of dealing with corporate banking. But where in this case is the role of the national bank capital and is there any such capital? 


\section{CONCLUSIONS}

The present research allows the following conclusions:

1. The net cash flows from operating activities of the entire researched group of companies after the crisis from 2007-2008 have increased significantly. This unexpected result is due to the rapid and continuously implemented conservative policy of the managers of these companies, mainly in terms of payments to suppliers.

2. The specific analysis shows that this unexpected but stable trend is formed by the following factors:

- Reduction in sales of credit;

- Increase in intercompany debt due to retention of payments to suppliers;

- Shortening the average term of collection of receivables from customers;

- Retention and slow increase in payments related to remunerations;

- Increase in the balance between the main incoming and outgoing operating cash flows.

3. The net cash flows from investment activities declined sharply in the years after the crisis. This somewhat expected trend manifested itself with an unexpected force. In 2009, the net cash flow for investments decreased more than 2 times compared to 2007. Although the results slightly improved in 2011, the research convincingly shows that industrial companies still can not get out of the investment shock, caused by the crisis.

4. The crisis caused an abrupt change in the net cash flows from financing activities. While before the crisis, they were incoming, after that they became mostly outgoing. Before the crisis, the cash inflows are formed mainly from proceeds of loans (debt capital), since in 2007 none of the companies issued shares and had no revenues in the form of equity. This result shows that after the crisis the industrial companies did not use the possibilities of the favorable financial leverage. Cash flows continue to leave the companies for service of old capital liabilities.

5. The research convincingly shows that the problem of financing of operating and investment activities of industrial companies has emerged as essential to their development $(7,8)$. In previous researches we have made concrete proposals for the gradual overcoming of this problem. I definitely think that it can not be solved by the "invisible hand" of the market and that there is a need for state intervention and regulation.

The research shows that currently there is no serious investment and financial potential for corporate growth of leading public companies from the Bulgarian industry. This is the main reason for the virtual absence of growth in the share prices of these companies. My prognosis is that in the next few years (2015-2020) there will be no serious investment interest in these companies.

\section{REFERENCES}

1. http://www.bse-sofia.bg/

2. International Accounting Standard №7 (IAS 7) - Statement of Cash Flows. - IAS 7 was reissued in December 1992, retitled in September 2007, and is operative for financial statements covering periods beginning on or after 1 January 1994.

3. National Accounting Standard №1 Presentation of Financial Statements.Promulgated State Gazette No. 30/07.04.2005, amended SG No. 86/26.10.2007, effective 1.01.2008.

4. National Accounting Standard №7 Statement of Cash Flows. - Promulgated State Gazette No. 30/07.04.2005, amended SG No. 86/26.10.2007, effective 1.01.2008.

5. Jury, T. Cash Flow Analysis and Forecasting: The Definitive Guide to Understanding and Using Published Cash Flow Data. John Wiley \& Sons, pp. 15-23, 2012.

6. Konarev, A. and S. Konstantinova. Security and Investments in the Industry. // Yearbook of CEA - Plovdiv, Volume XI, pp. 48-59, 2014.

7. Konarev, A. and S. Konstantinova. Reindustrialization and Financial Innovation. Scientific Proceedings. In: $10^{\text {th }}$ International Scientific Conference "Economics and Management of Innovation - Modern Theories and Practices". Varna: Publisher "Largo City", pp. 337-342, 2014.

8. Konarev, A. and S. Konstantinova. Reindustrialization and Smart Specialization of Bulgaria. - In: International Conference "Times of Uncertainty and Risks: Possibilities and Perspectives for Development. Plovdiv: UP "Paisii Hilendarski", pp. 359-366, 2014. 
